[Agr. Biol. Chem., Vol. 35, No. 7, p. 997 1006, 1971]

\title{
Studies on D-Glucose-isomerizing Enzyme from Bacillus coagulans, Strain HN-68
}

\author{
Part VI. The Role of Metal Ions on the Isomerization of \\ D-Glucose and D-Xylose by the Enzyme
}

\author{
By Gen-ichi Danno \\ Department of Agricultural Chemistry, Faculty of Agriculture, \\ Kobe University, Nada-ku, Kobe, Japan \\ Received September 14, 1970
}

\begin{abstract}
A functional role of $\mathrm{Co}^{2+}$ and $\mathrm{Mn}^{2+}$ in the D-glucose- and D-xylose-isomerizing reactions by D-glucose-isomerizing enzyme obtained from the cells of Bacillus coagulans, strain HN-68 was investigated. (1) The enzyme required $\mathrm{Co}^{2+}$ and $\mathrm{Mn}^{2+}$ for D-glucose- and D-xyloseisomerizing activities, respectively. (2) The enzyme which bound the metal, $\mathrm{Co}^{2+-}$ or $\mathrm{Mn}^{2+}$-enzyme, was active form. $\mathrm{Co}^{2+}$ was bound to the enzyme in a molar ratio of $4: 1$. (3) The rate of activation by metal ion varied with incubation $\mathrm{pH}$. (4) The binding of substrate to the enzyme was completely independent in the presence of metal ions. (5) However, it seemed unlikely that the $\mathrm{Co}^{2+}$ and $\mathrm{Mn}^{2+}$ acted as catalyzer on the reaction. (6) The binding sites for $\mathrm{Co}^{2+}$ and $\mathrm{Mn}^{2+}$ were different from each other. (7) The experimental data obtained might be successfully explained in terms of the suitable conformational changes for D-glucose and D-xylose isomerization, which were induced in the catalytic sites of the enzyme by binding $\mathrm{Co}^{2+}$ and $\mathrm{Mn}^{2+}$, respectively.
\end{abstract}

In the previous paper, ${ }^{1,2)}$ the author has reported some of the enzymatic and physicochemical properties of D-glucose-isomerizing enzyme which was prepared as crystalline form from the cells of Bacillus coagulans, strain HN-68. It has been proved that three activities of D-glucose, D-xylose and D-ribose isomerization occurred at the same active site of the enzyme molecule and that the enzyme may be considered to be $\mathrm{D}$-xylose isomerase (D-xylose ketol-isomerase, EG 5.3.1.5). The enzyme showed following interesting properties with regard to relationship between kind of metal ion added and substrate specificity: D-glucose- and D-ribose-isomerizing activities of the enzyme are specifically stimulated by

1) G. Danno, Agr. Biol. Chem., 34, 1795 (1970).

2) G. Danno, ibid., 34, 1805 (1970).
$\mathrm{Co}^{2+}$, while $\mathrm{D}$-xylose-isomerizing activity by $\mathrm{Mn}^{2+}$. The present paper describes the functional role of $\mathrm{Co}^{2+}$ and $\mathrm{Mn}^{2+}$ on the D-glucoseand D-xylose-isomerizing activities of the enzyme.

\section{MATERIALS AND METHODS}

Metal-free D-glucose-isomerizing enzyme. D-Glucoseisomerizing enzyme crystallized twice was prepared from the cells of Bacillus coagulans, strain HN-68, by the method described in previous paper.11 In order to remove metallic dication, the crystalline enzyme was dissolved in $0.01 \mathrm{M}$ EDTA and dialyzed successively against 500 volume of $0.01 \mathrm{M}$ EDTA and of distilled water. This preparation obtained showed no activities of the isomerization without adding mental ion.

Protein concentration. Amount of protein was 
measured spectrophotometrically at $280 \mathrm{~m} \mu$ with an extinction coefficient of 10.6 for $10 \mathrm{mg}$ of enzyme per $\mathrm{ml}$, in $0.1 \mathrm{M}$ acetate buffer $(\mathrm{pH} 6.0)$ and a $10 \mathrm{~mm}$ light path.11

Assay of enzyme activities. For the assay of Dglucose-isomerizing activity, the mixture containing $1 \mathrm{ml}$ of enzyme solution and $1 \mathrm{ml}$ of $0.03 \mathrm{M} \mathrm{CoCl}_{2}$ solution was preincubated for $20 \mathrm{~min}$ at $40^{\circ} \mathrm{C}$. To the mixture was added one $\mathrm{ml}$ of $0.3 \mathrm{M} \mathrm{D}$-glucose solution in $0.02 \mathrm{M}$ barbital buffer $(\mathrm{pH} 7.0$ ) and continued the incubation at $40^{\circ} \mathrm{C}$ for $30 \mathrm{~min}$. For the assay of $\mathrm{D}$-xylose-isomerizing activity, the mixture containing $1 \mathrm{ml}$ of enzyme solution and $1 \mathrm{~mL}$ of $0.03 \mathrm{M}$ $\mathrm{MnCl}_{2}$ solution was preincubated for $20 \mathrm{~min}$ at $40^{\circ} \mathrm{C}$, and then $1 \mathrm{ml}$ of $0.03 \mathrm{M} \mathrm{D}$-xylose solution in $0.3 \mathrm{M}$ borate buffer $(\mathrm{pH} 7.0$ ) was added to this mixture. After incubation at $40^{\circ} \mathrm{C}$ for $30 \mathrm{~min}$, the reaction was terminated by adding $1 \mathrm{ml}$ of $1.0 \mathrm{M}$ perchloric acid. For the assay of D-ribose-isomerizing activity, the procedure was the same as the assay of D-glucoseisomerizing activity, except that $1 \mathrm{ml}$ of $0.06 \mathrm{M} \mathrm{D}-$ ribose was used. The ketoses formed were determined by the cysteine-carbazole method and enzymatic activities were expressed as values of the optical density given in the determination method.

Chemicals. Chemicals for buffer, substrates and metal salts were special grade and purchased from the Wako Pure Chemical Industries, Ltd. Buffers, unless otherwise indicated, were sodium barbitalsodium acetate-hydrochloric acid system and adjusted to the desire $\mathrm{pH}$ at $40^{\circ} \mathrm{C}$. Buffers and solutions of substrates were prepared with deionized water, followed by extraction with $0.003 \%(\mathrm{w} / \mathrm{v})$ dithizone in $\mathrm{CCl}_{4}$ to remove trace metals, and were stored in polyethylene containers at $2 \sim 5^{\circ} \mathrm{C}$.

Equilibrium dialysis. Dialysis membrane bag was prepared from a cellulose tubing $(6.4 \mathrm{~mm})$ of Visking Company by the treatment with boiling EDTA solution, followed by washing with distilled water. In each experiment, $4 \mathrm{ml}$ of enzyme solution in the buffer (see below) was pipeted into the bag. The bag was placed in $6 \mathrm{ml}$ of the buffer containing $\mathrm{CoCl}_{2}$, and gently shaked for $48 \mathrm{hr}$ at $5^{\circ} \mathrm{C}$. Barbital buffer $(0.02 \mathrm{M})$ containing $0.1 \mathrm{M} \mathrm{NaCl}$ was used in all experiments. Amounts of $\mathrm{Co}^{2+}$ in the other solution were measured with an atomic absorption spectrophotometer (Hitachi, model 207).

\section{RESULTS AND DISGUSSION}

Effect of metal concentration on the activities As shown in Fig. 1, the enzyme required

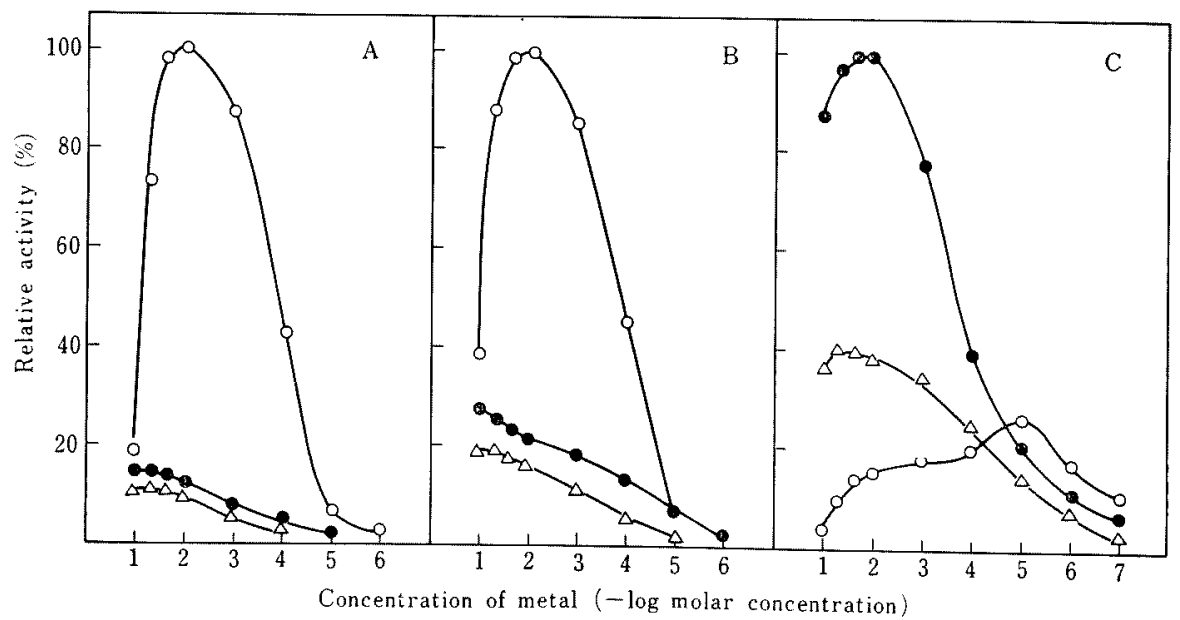

FIG. 1. Effect of $\mathrm{Co}^{2+}, \mathrm{Mn}^{2+}$ and $\mathrm{Mg}^{2+}$ Concentration on the D-Glucose-(A), D-Ribose-(B) and D-Xylose-(C) Isomerizing Activities.

The reaction mixtures were the same as those described under "Materials and Methods," except that the indicated concentration of metal salt was used.

O, $\mathrm{CoCl}_{2} ; \bullet, \mathrm{MnCl}_{2} ; \triangle, \mathrm{MgCl}_{2}$. 
$\mathrm{Co}^{2+}$ for both D-glucose- and D-ribose-isomerizing activities. The optimal concentration of $\mathrm{Co}^{2+}$ was $0.01 \mathrm{M}$. At higher concentration than $0.01 \mathrm{M}, \mathrm{Co}^{2+}$ showed inhibitory effect. For Dxylose-isomerizing activity of the enzyme, on the other hand, $\mathrm{Mn}^{2+}$ was essential, and optimal concentration of $\mathrm{Mn}^{2+}$ was about $0.01 \mathrm{M}$. Although the maximum D-xyloseisomerizing activity was obtained at a concentration of $10^{-5} \mathrm{M}$ of $\mathrm{Co}^{2+}$, the activity is corresponded to approximately a quarter of the maximum activity given by $\mathrm{Mn}^{2+}\left(10^{-2} \mathrm{M}\right)$. The activity with $\mathrm{Co}^{2+}\left(10^{-5} \mathrm{M}\right)$ showed a similar value obtained at the same concentration of $\mathrm{Mn}^{2+}$

Effect of the addition order of the components to the reaction mixtures on the reaction rate

When metal ion activates the enzyme reaction, there are generally two possible cases,

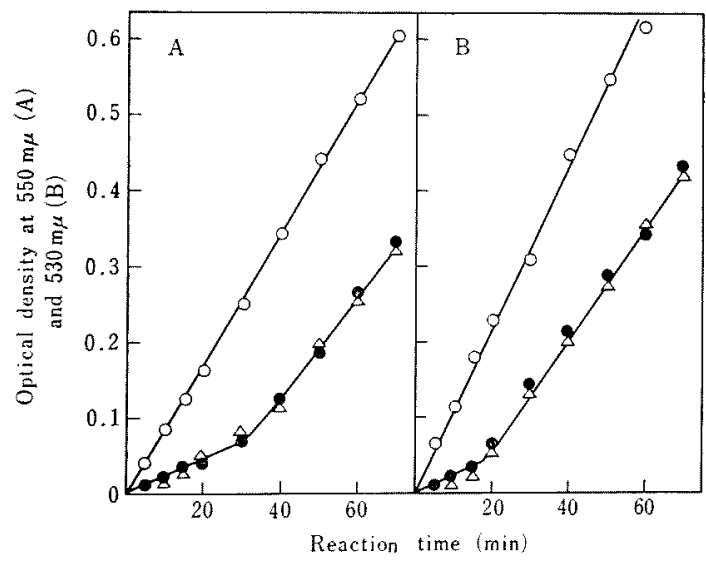

FIG. 2. Effect of the Adding Order of the Components in the Reaction Mixture on the Rate of $\mathrm{D}-$ Glucose (A) and D-Xylose (B) Isomerization.

Reaction systems: (A) $0.01 \mathrm{M} \mathrm{CoCl}_{2}, 0.2 \mathrm{M}$ Dglucose, $50 \mu \mathrm{g}$ enzyme, (B) $0.01 \mathrm{M} \mathrm{MnCl}_{2}, 0.01 \mathrm{M}$ $\mathrm{D}$-xylose, $4 \mu \mathrm{g}$ enzyme, $0.007 \mathrm{M}$ barbital buffer ( $\mathrm{pH} 7.0$ ), total volume, $5 \mathrm{ml}$.

$O$, mixture of enzyme and metal was incubated at $20^{\circ} \mathrm{C}$ for $4 \mathrm{hr}$ and then added substrate; $\triangle$, substrate and metal was incubated at $20^{\circ} \mathrm{C}$ for $4 \mathrm{hr}$ and then added enzyme; $\boldsymbol{0}$, enzyme metal and substrate were mixed simultaneously. i.e., metal ion can bind to a enzyme or/and substrate and form active enzyme or/and active substrate. Therefore, effect of preincubation of the enzyme or substrate with metal ion was investigated. As shown in Fig. 2, when the D-glucose-isomerizing activity was assayed without preincubation with $\mathrm{Co}^{2+}$, the initial reaction velocity was very low and increased with time. After the preincubation with $\mathrm{Co}^{2+}$ for $4 \mathrm{hr}$ at $20^{\circ} \mathrm{C}$, the reaction started linially from zero time. When the enzyme was added to the mixture in which D-glucose was preincubated with $\mathrm{Co}^{2+}$ for $4 \mathrm{hr}$ at $20^{\circ} \mathrm{C}$, the reaction velocity was little. The similar results were also obtained on D-xylose-isomerizing system composed of the enzyme, $\mathrm{Mn}^{2+}$ and D-xylose. These results suggested that the primary reaction in the activation process was a binding of metal ion to the enzyme protein, so that $\mathrm{Co}^{2+}$ - and $\mathrm{Mn}^{2+}$-enzyme complexes were active form of the enzyme.

Effect of $p H$ on the rate of activation of the enzyme by $\mathrm{Co}^{2+}$ and $\mathrm{Mn}^{2+}$

Activation rate was determined after the preincubation for $10 \mathrm{~min}$ at $20^{\circ} \mathrm{G}$ at various $\mathrm{pHs}$ given by barbital buffer and expressed

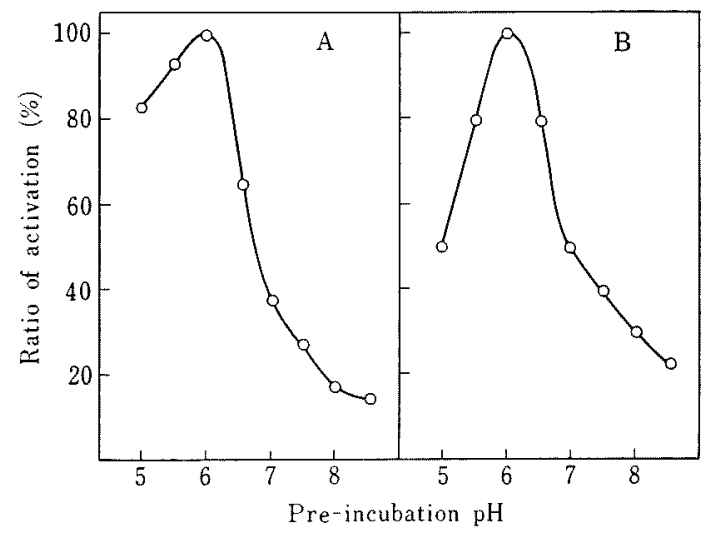

FIG. 3. Effect of $\mathrm{pH}$ on the Rate of Activation of the Enzyme with $\mathrm{Co}^{2+}$ and $\mathrm{Mn}^{2+}$.

Experimental condition was described in the text. A, D-glucose-isomerizing activity $\left(\mathrm{Co}^{2+}\right), \mathrm{B}$, $\mathrm{D}$-xylose-isomerizing activity $\left(\mathrm{Mn}^{2+}\right)$. 
as relative activity. As shown in Fig. 3, the activation rate was markedly $\mathrm{pH}$-dependent, i.e., the activation by the metal ion was most rapid at $\mathrm{pH} 6.0$, and was slow at both side

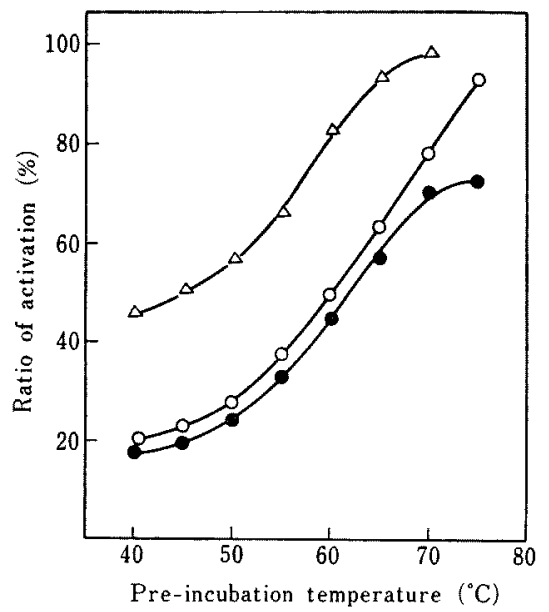

F1G. 4. Effect of Temperature on the Rate of Activation of the Enzyme with $\mathrm{Co}^{2+}$.

The enzyme solutions $(50 \mu \mathrm{g})$ in barbital buffer were pre-incubated at indicated temperature with $\mathrm{CoCl}_{2}(0.01 \mathrm{M})$. After incubation for $10 \mathrm{~min}$, the solution was cooled immediately in an ice bath, and then D-glucose was added and activity was measured.

$\triangle, \mathrm{pH} 6.7 ; \mathrm{O}, \mathrm{pH} 7.0 ; \bullet, \mathrm{pH} 7.5$.

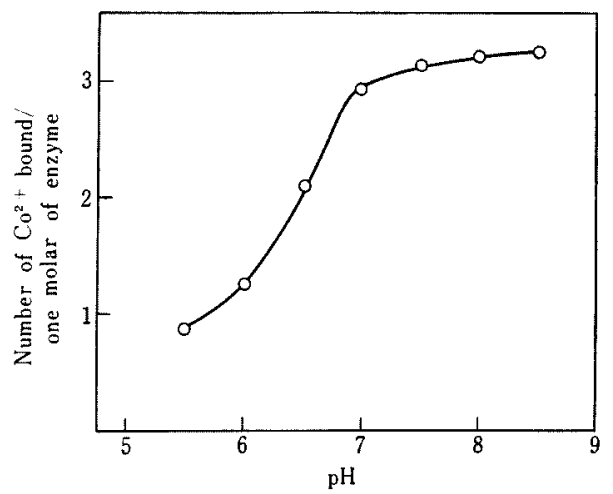

FIG. 5. Effect of $\mathrm{pH}$ on the Binding of $\mathrm{Co}^{2+}$ to the Enzyme under Fixed Concentration of $\mathrm{Co}^{2+}$.

Number of $\mathrm{Co}^{2+}$ bound to the enzyme was determined by equilibrium dialysis as described in "Materials and Methods." of the $\mathrm{pH}$. During the $10-\mathrm{min}$ preincubation at $\mathrm{pH} 7.0$, the activity reached only $40 \sim 50 \%$ levels of the maximum activity. The effect of temperature during $10-\mathrm{min}$ incubation with $\mathrm{Co}^{2+}$ on activation rate was measured. As shown in Fig. 4, the activation rate which induced by preincubation increased with a rise of temperature. Molar ratio of $\mathrm{Co}^{2+}$ bound to the enzyme under fixed concentration of $\mathrm{Co}^{2+}$ increased with $\mathrm{pH}$ (Fig. 5). From above data, it was considered that the enzyme molecule forms a structure which metal ion is rapidly bound to the enzyme at $\mathrm{pH} 6.0$.

\section{Kinetics of activation by metal ions}

When metal ion forms an essential part in active center of the enzyme, there are two possible cases. First, it is assumed that metal ion is located in the binding site of the active center of the enzyme, where metal ion acts as a conecting point of the substrate as shown for carboxypeptidase ${ }^{31}$ and D-xylose ketolisomerase from Lactobacillus brevis. " If only the enzyme-metal ion complex is able to combine with substrate, following reaction mechanism may be considered

$$
\begin{aligned}
& K a \quad E+M \rightleftarrows E M, \\
& K m \quad E M+S \rightleftarrows E M S \stackrel{k}{\rightarrow} E M+\text { Product. }
\end{aligned}
$$

The equation for the velocity is as follows:

$$
v=\frac{k e}{1+\frac{K m}{s}\left(1+\frac{K a}{a}\right)}
$$

where $a, s$ and $e$ are the concentrations of metal ion, substrate and enzyme, respectively, and $\mathrm{Km}$ represents the Michaeris constant and $K a$ is the dissociation constant of the enzymemetal complex. For testing the applicability of equation (2) to the experimental data, it is conveniently written in a form suggested

3) M. Dixon and E. C. Webb, "Enzyme," Academic Press Inc., N. Y., 1964.

4) K. Yamanaka, Mem. Fac. Agr. Kagawa Univ., 16, (1963). 
by Lineweaver and Burk:

$$
\frac{1}{v}=\left(1+\frac{K a}{a}\right) \frac{1}{V} \frac{K m}{s}+\frac{1}{V}
$$

Second, the metal ion acts as stimulatant of the catalytic function of the enzyme, as shown for beta-methylasparatase." If the binding of substrate to the enzyme is not subjected to the metal ion, following reactions may be considered

$$
\begin{aligned}
& \text { Ks } \quad E+S \rightleftarrows E S \text {, } \\
& K a \quad E+M \rightleftharpoons E M \text {, } \\
& K m \quad E M+S \div E M S \stackrel{k}{\rightarrow} E M+\text { Product . }
\end{aligned}
$$

The equation for the velocity is as follows:

$$
v=\frac{k e}{\left(1+\frac{K a}{a}\right) \frac{K m}{s}+\left(\frac{K a}{a} \cdot \frac{K m}{K s}+1\right)}
$$

where $a, s$ and $e$ are the concentrations of metal ion, substrate and enzyme, respectively,

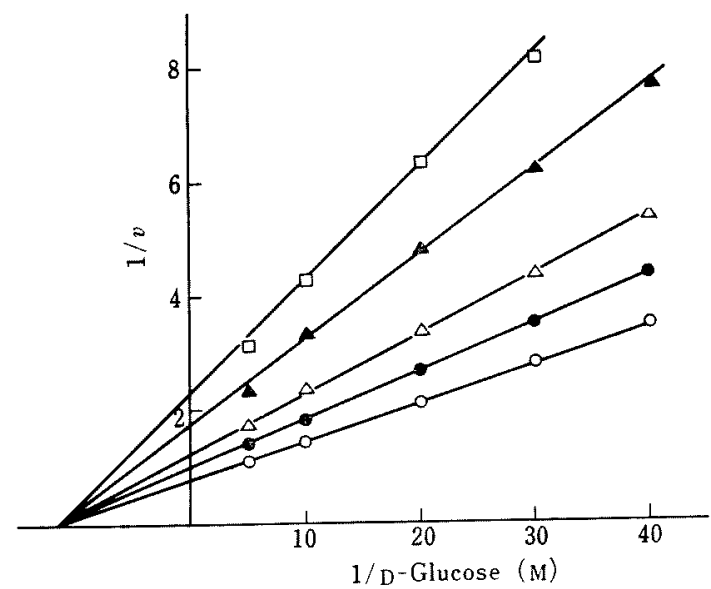

FIG. 6. Double Reciprocal Plots of the Reaction Rate and Concentration of D-Glucose at the Indicated Concentration of $\mathrm{Co}^{2+}$.

Experimental condition was the same as described in "Materials and Methods," except that indicated concentration of $\mathrm{Co}^{2+}$ and D-glucose were used. Concentration of $\mathrm{CoCl}_{2}: \mathrm{O}, \mathrm{I0}^{-3}$; ๑ $5 \times 10^{-4} ; \Delta, 2.5 \times 10^{-4} ; \Delta, 1.25 \times 10^{-4} ; \square$, $6.3 \times 10^{-5} \mathrm{M}$.

5) H. J. Bright, J. Biol. Chem., 240, 1198 (1965).

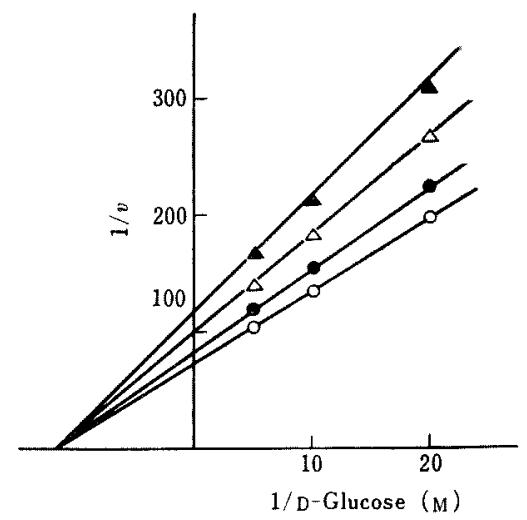

FIG. 7. Double Reciplocal Plots of the Reaction Rate and Concentration of $D$-Glucose at the Indicated Concentration of $\mathrm{Mn}^{2+}$.

Experimental condition was the same as described in "Materials and Methods," except that indicated concentration of $\mathrm{Mn}^{2+}$ and $\mathrm{D}$-glucose were used. Concentration of $\mathrm{MnCl}_{2}$ : $\mathrm{O}, 10^{-3}$; $5 \times 10^{-4} ; \Delta, 2.5 \times 10^{-4} ; \Delta, 1.25 \times 10^{-4} \mathrm{M}$.

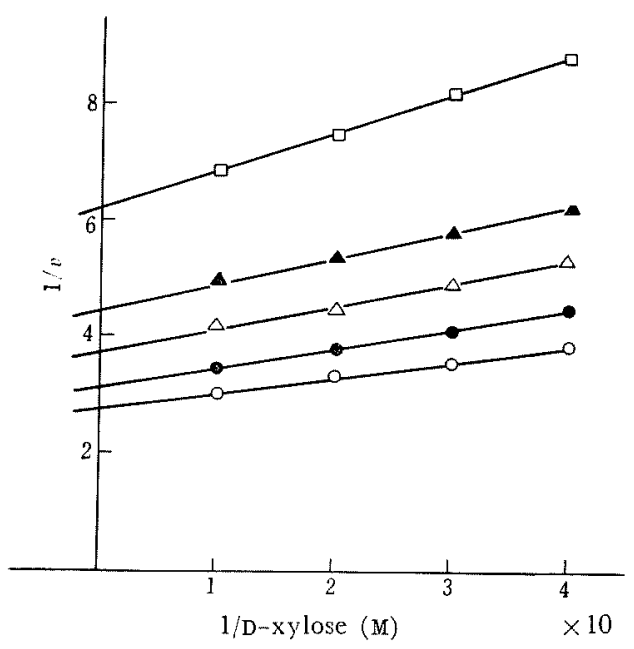

FIG. 8. Double Reciplocal Plots of the Reaction Rate and D-Xylose Concentrations at the Indicated Concentrations of $\mathrm{Mn}^{2+}$.

Experimental condition was the same as described in "Materials and Methods," except that indicated concentration of metal and D-xylose were used. Concentration of $\mathrm{MnCl}_{2}: 0,10^{-3}$; $5 \times 10^{-4} ; \Delta, \quad 2.5 \times 10^{-4} ; \Delta, \quad 1.25 \times 10^{-4} ; \square, 6.3$ $\times 10^{-5} \mathrm{M}$. 
and $K m$ represents the Michaeris constant and $K a$ is the dissociation constant of the enzymemetal complex. $K s$ is replaced by $K m$ and then equation (5) is reformed as follows:

$$
\frac{1}{v}=\frac{K m}{V}\left(1+\frac{a}{K a}\right) \frac{1}{s}+\frac{1}{V}\left(1+\frac{a}{K a}\right)
$$

In order to clarify which mechanism is more appropriate as a function of metal for isomerizing reaction in the $\mathrm{D}$-glucose-isomerizing enzyme, the following experiments were performed. The reaction rates of $D$-glucose isomerization at the varing level of divalent cations, such as $\mathrm{Co}^{2+}$ and $\mathrm{Mn}^{2+}$, were plotted in double reciprocal forms. As shown in Figs. 6 and 7, the lines obtained at each concentration levels of $\mathrm{Co}^{2+}$ gave the same intercepts on abscissa, this results indicated that $K m$ value was not affected by the concentration of the cations. As shown in Fig. 8, a similer results were obtained for D-xyloseisomerizing reaction. Since above data clearly showed that the values of the intersection on the abscissa remained unchanged when concentrations of metal ion was varied, equation (6) is fit for this data. Thus, it was suggested that the function of $\mathrm{Co}^{2+}$ and $\mathrm{Mn}^{2+}$ in the $\mathrm{D}$-glucose- and $\mathrm{D}$-xylose-isomerizing reactions might be a stimulation of the catalytic activity on the catalytic site of the enzyme.

Equation (6) is reformed as a function of metal concentration

$$
\frac{1}{v}=\left(1+\frac{K m}{s}\right) \frac{K a}{V} \cdot \frac{1}{a}+\left(1+\frac{K m}{s}\right) \frac{1}{V} .
$$

Equation (7) predicts that the intersection of straight lines occurs on the abscissa in double reciprocal plot of reaction rate against metal ion concentration at different substrate concentrations. The numerical value of $1 / a$ at the point of intersection of lines in the plot of $1 / v$ versus $1 / a$ indicates the value of $-1 / K a$. The data in Figs. 6 and 8 are replotted in Fig. 9 and 10, respectively, as a function of $\mathrm{Co}^{2+}$ and $\mathrm{Mn}^{2+}$ at a constant concentration of the substrate. Dissociation constants $(K a)$ of enzyme- $\mathrm{Co}^{2+}$ and enzyme- $\mathrm{Mn}^{2+}$ was calculated to be $1.8 \times 10^{-4} \mathrm{M}$ and $9 \times 10^{-5} \mathrm{M}$, respectively. This value is in good agreement with the value of $4.5 \times 10^{-5} \mathrm{M}$ obtained from the equilibrium dialysis experiment which will be described below. That is, the dis-

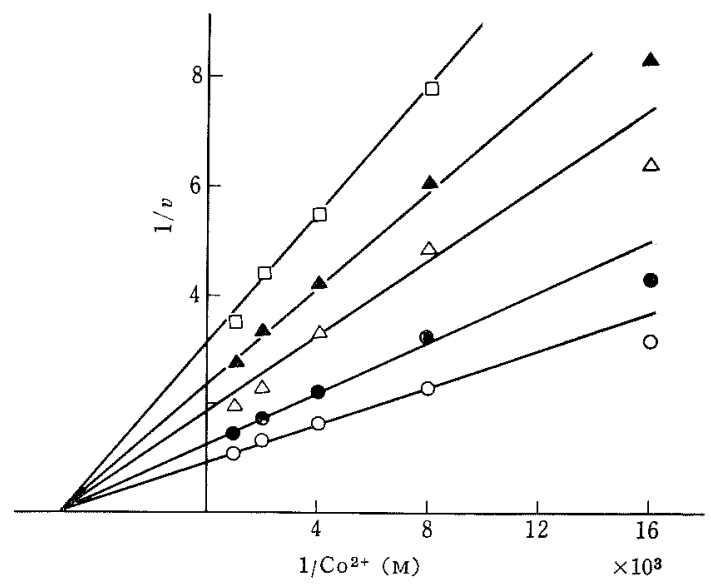

FIG. 9. Double Reciprocal Plots of the Reaction Rate and $\mathrm{Co}^{2+}$ Concentrations at the Indicated Concentrations of $\mathrm{D}$-Glucose.

Data of Fig. 6 were replotted. D-Glucose concentration: $O, 0.2 ; 0,0.1 ; \Delta, 0.05 ; \Delta, 0.033$; $\square, 0.025 \mathrm{M}$.

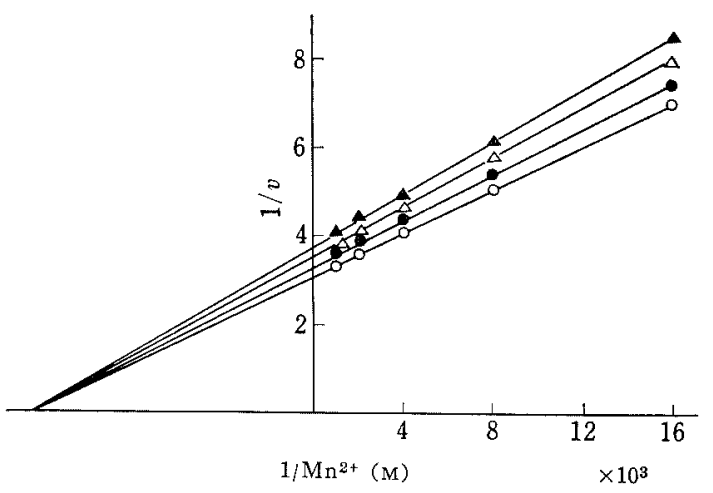

FIG. 10. Double Reciprocal Plots of the Reaction Rate and $\mathrm{Mn}^{2+}$ Concentrations at the Indicated Concentrations of D-Xylose.

Data of Fig. 8 were replotted. Concentrations of D-xylose: $O, 0.01 ; 0,0.005 ; \Delta, 0.0033$; $0.0025 \mathrm{M}$. 


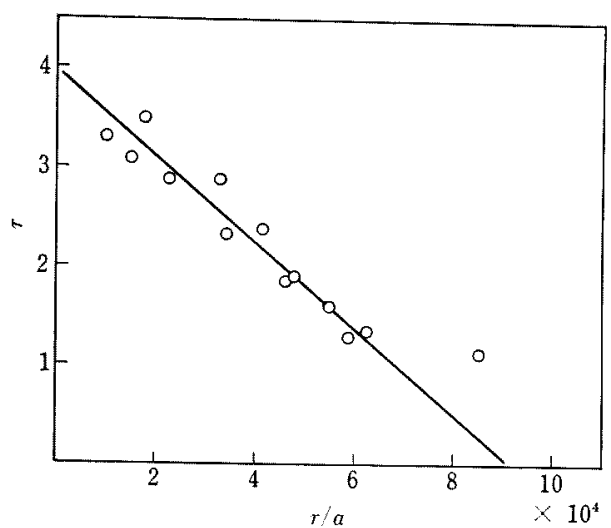

FIG. 11. Binding of $\mathrm{Co}^{2+}$ by the Enzyme at $\mathrm{pH} 7.0$.

$r$, the number of molecules of $\mathrm{Co}^{2+}$ bound per molecule of protein was determined by the equilibrium dialysis method as described in "Materials and Methods."

sociation constant ( $K a$ ) by the equilibrium dialysis method was calculated from the following equation (6)

$$
r \frac{K a}{a}=n-r
$$

where $r$ is the average number of $\mathrm{Co}^{2+}$ bound per molecule of the enzyme, $a$ is concentration of free $\mathrm{Co}^{2+}$, and $n$ is the total number of binding sites in the enzyme. A plot of $r$ versus $r / a$ from the results of several $\mathrm{Co}^{2+}$. binding experiments is shown in Fig. 11. The line had the parameters of $n=4$ and $K a=4.5 \times 10^{-5} \mathrm{M}$.

\section{Effect of $\mathrm{Co}^{2+}$ and $\mathrm{Mn}^{2+}$ on nonenzymatic iso- merization}

Effects of $\mathrm{Co}^{2+}$ and $\mathrm{Mn}^{2+}$ for nonenzymatic isomerization of the sugars were investigated. Solutions containing D-glucose or D-xylose, metal salt, and barbital buffer were adjusted to $\mathrm{pH} 6.8$ with $0.5 \mathrm{M} \mathrm{NaOH}$ and were incubated at $50^{\circ} \mathrm{C}$ in screw-capped test tubes. At various time intervals, aliquots were re-

6) J.E. Hayes and S. F. Velick, J. Biol. Chem., 207, 225 (1954).

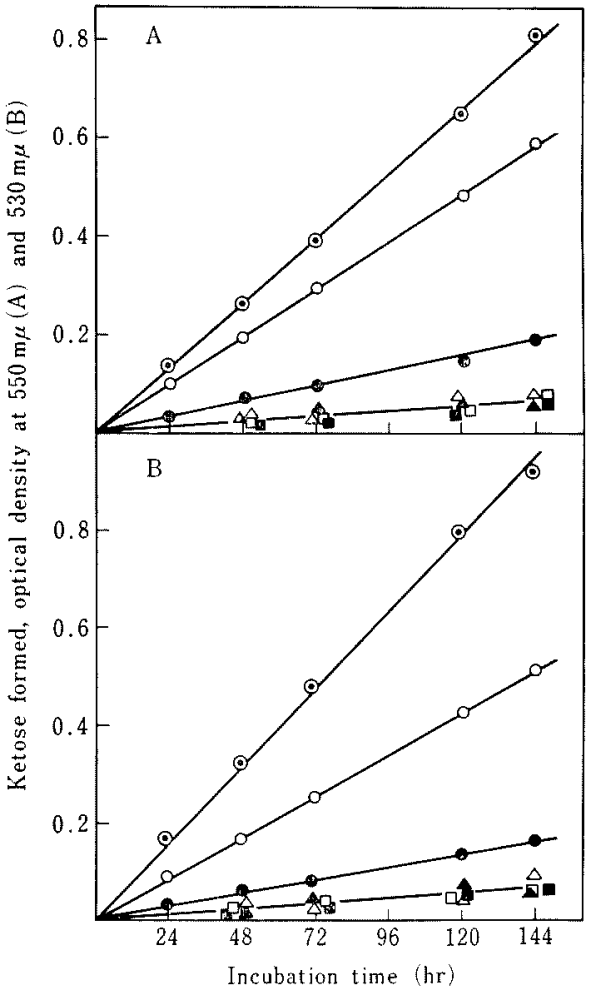

FIG. 12. Effect of Metal Ion on the Nonenzymatic Isomerization of D-Glucose (A) and D-Xylose (B).

$\mathrm{D}$-Glucose or D-xylose ( $1 \mathrm{~m}$ mole) was incubated at $50^{\circ} \mathrm{G}$ with metal salt ( $1 \mathrm{~m}$ mole in chloride form) in a final volume of $10 \mathrm{ml}$. The $\mathrm{pH}$ of the incubation mixtures was 6.8 , and barbital buffer $(0.007 \mathrm{M})$ was employed. At the indicated intervals, $0.2 \mathrm{ml}$ aliquots were withdrawn from the incubation mixture and diluted with water and ketoses formed were determined by cysteinecarbazole method: $\mathbf{n}$, no addition; (๑), $\mathrm{Ni}^{2+} ; \mathrm{O}$, $\mathrm{Co}^{2+} ;-\mathrm{Mn}^{2+} ; \triangle, \mathrm{Mg}^{2+} ; \Delta, \mathrm{Na}^{+} ; \square$, EDTA

moved from the incubation mixtures and diluted with water, and ketoses formed were determined by cysteine-carbazole method. As shown in Figs. 12 and 13, stimulative effects of metal salt on the nonenzymatic isomerization were observed with a slow rate. Among the metal salts used here, $\mathrm{Ni}^{2+}$ gave the highest effect on the isomerization of both D-glucose and D-xylose. Thus, a funtional role of metal ion in the enzymatic reaction 


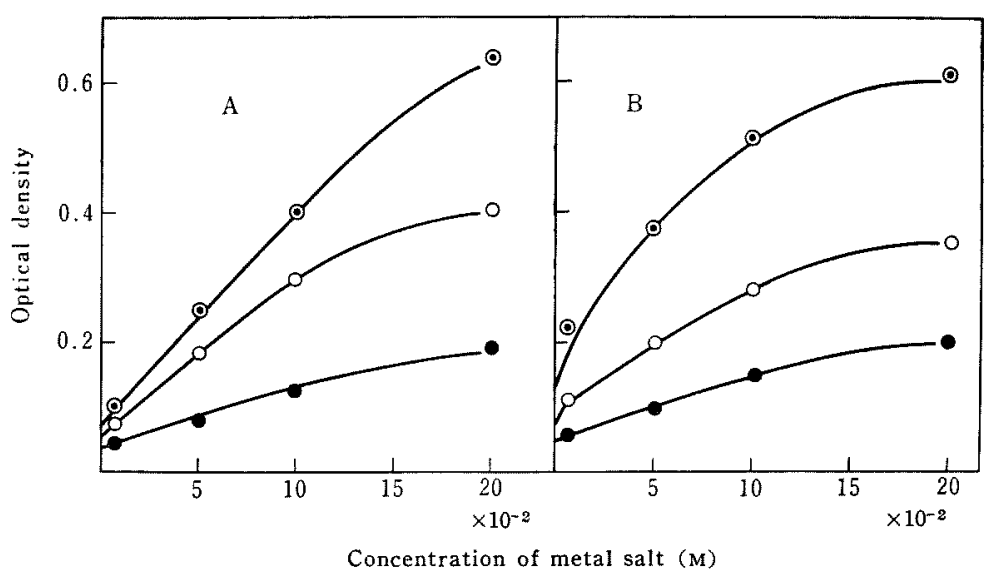

FIG. 13. Nonenzymatic Isomerization of $D-G$-Gucose (A) and $D-X y l o s e(B)$ as Function of Metal Salt Concentration.

Experimental condition was the same as described in Fig. 12, except that indicated concentration of metal salt was used and reaction time was $70 \mathrm{hr}$ : $\odot$, $\mathrm{NiCl}_{2} ; O, \mathrm{CoCl}_{2} ; \bullet, \mathrm{MnCl}_{2}$.

may be thought to be an conformational change in enzyme molecule, rather than in stimulating effect for the isomerization.

Difference of the binding site of $\mathrm{Co}^{2+}$ and $\mathrm{Mn}^{2+}$

It is of interest to determine whether the binding site of $\mathrm{Co}^{2+}$ and $\mathrm{Mn}^{2+}$ was the same or not. $\mathrm{Mn}^{2+}$ inhibited D-glucose-isomerizing activity by $\mathrm{Co}^{2+}$-activated enzyme. Figure 14 is double reciprocal plot of the reaction rate as a function of $\mathrm{Co}^{2+}$ concentration under a fixed level of D-glucose and in the presence or absence of $\mathrm{Mn}^{2+}\left(10^{-4} \mathrm{M}\right)$. The mode of inhibiting action by $\mathrm{Mn}^{2+}$ was found to be partially non-competitive. This results means that $\mathrm{Co}^{2+}$ and $\mathrm{Mn}^{2+}$ did not compete at the binding site. Furthermore, this is strongly supported from following experiment of inhibition of $\mathrm{Ni}^{2+}$. Figures 15 and 16 are double reciprocal plots of the reaction rate as a function of $\mathrm{Co}^{2+}$ or $\mathrm{Mn}^{2+}$ concentration under a fixed level of D-glucose or D-xylose, and in the presence or absence of $\mathrm{Ni}^{2+}\left(10^{-4} \mathrm{M}\right)$. On the D-glucose-isomerizing activity by $\mathrm{Co}^{2+}$ activated enzyme, $\mathrm{Ni}^{2+}$ inhibited the activity in competitive type as shown in Fig. 15. On

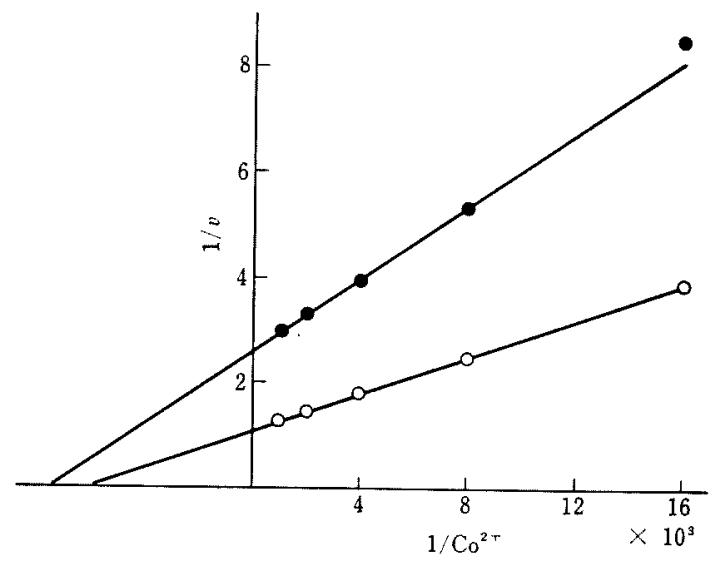

FIG. 14. Double Reciprocal Plots of the Reaction Rate and $\mathrm{Co}^{2+}$ Concentration in the Presence or Absence of $\mathrm{Mn}^{2+}$ and at a Fixed Concentration of D-Glucose.

Experimental condition was the same as described in "Materials and Methods," except that indicated concentration of metal ion and D-glucose $(0.3 \mathrm{M})$ were used: 9 , with $\mathrm{MnCl}_{2}\left(10^{-4} \mathrm{M}\right) ; 0$, without $\mathrm{MnCl}_{2}$.

the D-xylose-isomerizing activity by $\mathrm{Mn}^{2+}$. activated enzyme, however, $\mathrm{Ni}^{2+}$ inhibited the activity in non-competitive type. Since 


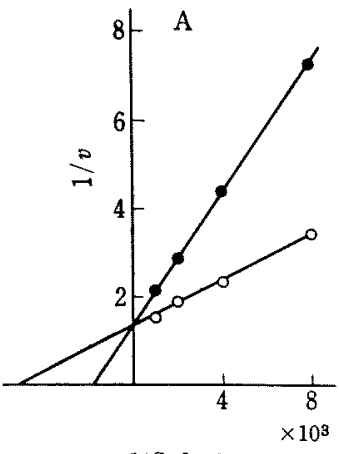

$1 / \mathrm{Co}^{2+}(\mathrm{M})$

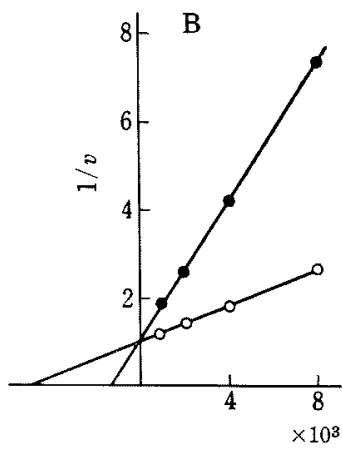

$1 / \mathrm{Co}^{2+}(\mathrm{M})$
FIG. 15. Double Reciprocal Plots of the Reaction Rate and $\mathrm{Co}^{2+}$ Concentrations in the Presence or Absence of $\mathrm{Ni}^{2+}$ and at Fixed Concentration of D-Glucose (A) or D-Ribose (B).

Experimental condition was the same as described in "Materials and Methods," except that indicated concentrations of metal and substrate (D-glucose, $0.3 \mathrm{M}$; D-ribose, $0.2 \mathrm{M}$ ) were used: with $\mathrm{Ni}^{2+}\left(10^{-4} \mathrm{M}\right) ; \mathrm{O}$, without $\mathrm{Ni}^{2+}$.

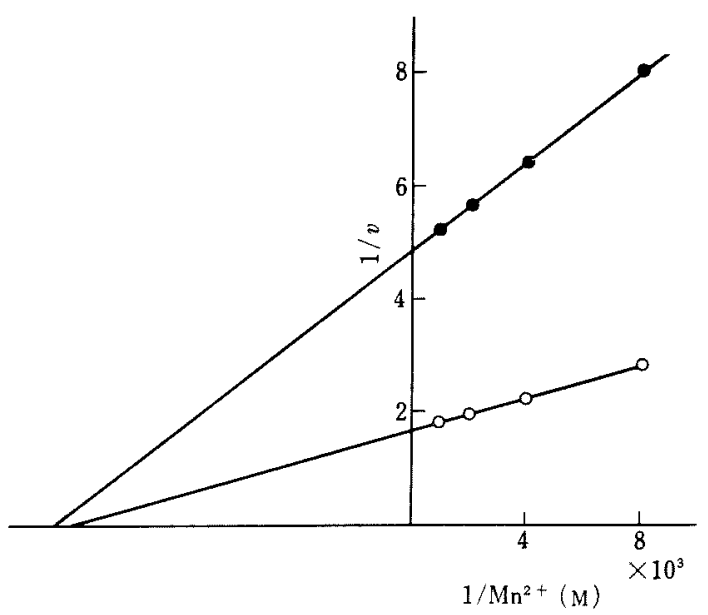

FIG. 16. Double Reciprocal Plots of the Reaction Rate and $\mathrm{Mn}^{2+}$ Concentrations in the Presence or Absence of $\mathrm{Ni}^{2+}$.

Experimental condition was the same as described in "Materials and Methods," except that indicated concentrations of metal ion and $\mathrm{D}$-xylose $(0.1 \mathrm{M})$ were used without $\mathrm{Ni}^{2+}$. the inhibition of $\mathrm{Ni}^{2+}$ was competitive for $\mathrm{Co}^{2+}$ and non-competitive for $\mathrm{Mn}^{2+}$, it is concluded that the binding site of $\mathrm{Co}^{2+}$ and $\mathrm{Mn}^{2+}$ on the enzyme is different from each other.

\section{Mechanism proposed for activation by metal ions}

On the basis of the results described above, a possible function of metal ions for the isomerizing reaction and for substrate specificity of the enzyme is proposed, and is illustrated in Fig. 17. The assumption has been made that on the active center the enzyme protein has three binding sites; binding site (1), (2) and (3) for substrate, $\mathrm{Co}^{2+}$ and $\mathrm{Mn}^{2+}$, respectively. On the site (1), D-glucose (or D-ribose) or D-xylose may bind to the enzyme with an

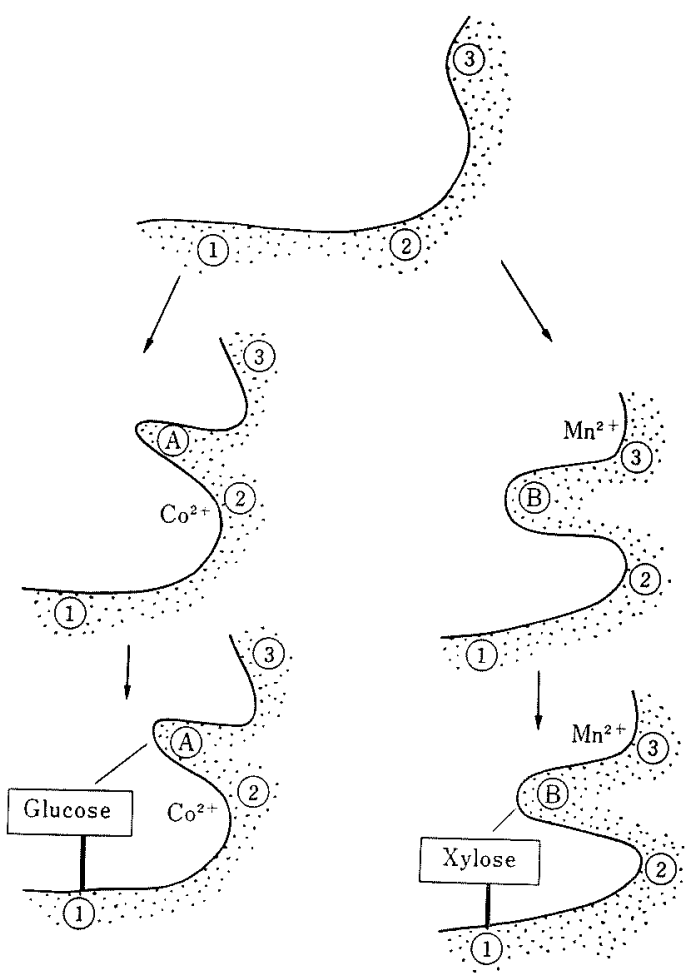

FIG. 17. Proposed Mechanism for Activation of the Enzyme with $\mathrm{Co}^{2+}$ and $\mathrm{Mn}^{2+}$.

Details are described in the text. 
affinity which is not affected by metal ions. isomerization is induced.

When $\mathrm{Co}^{2+}$ binds site (2), the conformational change in the enzyme molecule may occur to give an active form (form A) showing high activity for D-glucose isomerization. When $\mathrm{Mn}^{2+}$ bind to site (3), another active form (form B) having high activity for D-xylose

Acknowledgements. The author wishes to expres: his gratitude to Dr. Sadahiko Yoshimura, Emeritus Professor of Kobe University, for his kind guidance and encouragement, and to Dr. Masato Natake, Kobe University, for his helpful discussion. 